\title{
EDUCAÇÃO, FORMAÇÃO PROFISSIONAL E CERTIFICAÇÃO DE CONHECIMENTOS: CONSIDERAÇÕES SOBRE UMA POLÍTICA PÚBLICA DE CERTIFICAÇẨO PROFISSIONAL'
}

\author{
Carmen Sylvia Vidigal Moraes ${ }^{* *}$ \\ Sebastiāo Lopes Neto ${ }^{* * *}$
}

\begin{abstract}
É preciso não duvidar: o que pode levar à superação da crise atual do mundo, da falência de um modo de produção, de consumo, de vida, é a capacidade mesma de pensar.
\end{abstract}

(Pierre Naville, 1945)

\begin{abstract}
RESUMO: Existem, no Brasil, duas formas de certificação, organizadas de acordo com os distintos propósitos, público-alvo e interesses que as orientam. De um lado, a certificação regulamentada do ensino nos seus diferentes níveis, mas mantendo a dissociação entre certificação e formação profissional na "educação profissional básica"; e, de outro, as medidas alinhadas às demandas do mercado, interessadas no reconhecimento formal de competências adquiridas no exercício de trabalho, com o objetivo de aumentar a competitividade. As reflexôes aqui realizadas visam contribuir para a elaboração de uma política pública que integre a formação profissional no sistema nacional de educação e normalize a validação das qualificações profissionais no sistema escolar, promovendo a superação da dicotomia entre educação/certificação escolar e formação/certificação profissional, e possibilitando, aos candidatos à certificação profissional, o reconhecimento social e o aproveitamento de seus conhecimentos para fins de continuidade de estudos e de inserção e progressão profissional.
\end{abstract}

Palavras-chave: Trabalho. Educação. Formação profissional. Certificação. Competências. Política pública.

* Agradecemos a leitura atenta e as sugestōes de Maria Ciavatta, Neise Deluiz e Giuseppe La Barbera.

** Doutora em educação e professora da Faculdade de Educação da Universidade de São Paulo (USP).E-mail: moraescs@usp.br

*** Diretor executivo do Intercâmbio, Informações, Estudos e Pesquisas (IIEP). E-mail: iiep@iiep.org.br

Educ. Soc., Campinas, vol. 26, n. 93, p. 1435-1469, Set./Dez. 2005

Disponível em <http://www.cedes.unicamp.br> 
Educação, formação profissional e certificação de conhecimentos...

EDUCATION, VOCATIONAL TRAINING AND CERTIFICATION OF KNOWLEDGE: CONSIDERATIONS ON PUBLIC POLICIES FOR PROFESSIONAL CERTIFICATION

ABSTRACT: The two Brazilian forms of certification are organized according to their goals, target public and the interests that guide them: 1) The regulated certification of teaching on its different levels, which keeps the difference between professional certification and vocational training in the "basic professional education". 2) The measures in line with the demands of the labour market, which are interested in the formal recognition of abilities acquired at work, in order to increase competitiveness. These reflections intend to help elaborate public policies that integrate vocational training into the national education system and regulate the validation of professional qualifications in the school system. This would overcome the dichotomy between school education/certification and vocational training/professional certification, and give social recognition to the candidates to professional certification, allowing them to use their knowledge to continue their studies, and professionally insert themselves and grow.

Key words: Labour. Education. Vocational training. Certification. Skills. Public policies.

\section{Introdução}

$\mathbb{E}$ xistem, hoje, no Brasil, duas formas de certificação, organizadas de acordo com os distintos propósitos, público-alvo e grupos de interesse que as orientam. De um lado, a certificação regulamentada do ensino de diferentes níveis - fundamental, médio e superior, incluindo o ensino médio técnico, mas mantendo a dissociação entre certificação e formação profissional (a educação profissional básica); e, de outro lado, as medidas "alinhadas com as demandas do mercado de trabalho, interessadas no reconhecimento formal de competências adquiridas e acumuladas no exercício de trabalho", com a finalidade de aumentar a competitividade do sistema produtivo e/ou "organizar e valorizar o mercado de trabalho" (Alexim \& Lopes, 2003, p. 3-4).

As reflexões aqui realizadas têm por objetivo contribuir para a elaboração de uma política pública que integre a formação profissional no sistema nacional de educação, e que, portanto, normalize o reconhecimento e a validação das qualificações profissionais no âmbito do sistema escolar, promovendo a superação da dicotomia entre educação/certificação 
escolar e formação/certificação profissional e viabilizando, aos candidatos à certificação profissional, o reconhecimento social e o aproveitamento de seus conhecimentos para fins tanto de continuidade de estudos e certificação escolar quanto de inserção e progressão profissional.

Tal proposição sustenta-se nos seguintes pressupostos:

- Cabe ao Poder Público, representado, nesse caso, pelo Ministério da Educação e pelo Ministério do Trabalho, garantir a definição e aplicação de normas e critérios públicos que conciliem as aspiraçõos dos indivíduos e as necessidades coletivas.

- A concepção republicana de educação privilegia a formação do cidadão. A formação profissional deve estar integrada a este objetivo, formando o "cidadão produtor", o que implica uma proposta de certificação capaz de superar a dualidade entre formação geral e formação profissional, e, portanto, a avaliação meramente técnica ou operacional do desempenho do trabalhador.

- A certificação representa o resultado natural da formação e sanciona o percurso escolar dos alunos.

- Os diplomas profissionais têm dupla finalidade, isto é, eles devem permitir simultaneamente o prosseguimento nos estudos e o acesso ao mercado de trabalho.

A concretização dessas propostas implica o enfrentamento de diferentes questōes conceituais e dificuldades de ordem prática, tais como: o acesso à formação e à certificação, a dissociação entre certificação e formação, a desarticulação entre formação geral e formação profissional, e entre certificação e classificação das ocupações ( $\mathrm{CBO})$, que estão no centro dos debates atuais.

Com este quadro de preocupações, propomo-nos a analisar algumas das questões relacionadas à concepção, organização e ao financiamento de um sistema nacional de certificação no Brasil.

Situando o tema: a relação entre educação escolar, formação e certificação profissional

A discussão sobre certificação para fins escolares e profissionais foi impulsionada pela implantação das Diretrizes e Bases da Educação Na- 
Educação, formação profissional e certificação de conhecimentos...

cional (LDB) (Lei n. 9.394/96) e por diversos pareceres, portarias, mas, particularmente, pelo Decreto n. 2.208/97, que alterou o ensino médio de nível técnico.

Esse decreto instituiu um sistema de educação profissional, com três níveis: básico (abrangendo a aprendizagem ou cursos de curta duração para adultos), o técnico e o tecnológico, em nível superior.

O ensino técnico foi definido como independente do ensino médio, isto é, era facultado ao aluno cursar o ensino técnico concomitante ao ensino médio, depois dele ou até mesmo de maneira independente. Os antigos cursos integrados, que ofereciam num mesmo currículo a educação geral de nível médio e a educação técnico-profissional, foram literalmente proibidos, tolerados apenas no caso das escolas agrotécnicas.

A desvinculação entre o ensino médio e o ensino técnico, ou seja, entre a formação geral e a formação profissional, foi apresentada, pelo governo da época, como avanço democrático, pois permitiria a "qualificação e a reprofissionalização dos trabalhadores, independentemente de escolaridade prévia" (Decreto n. 2.208, artigo $3^{\circ}$ ), e a experiência profissional e/ou conhecimentos poderiam ser "(...) objeto de avaliação, reconhecimento e certificação para prosseguimento ou conclusão de estudos” (Portaria n. 646/97).

Neste sentido, os cursos técnicos, desvinculados do ensino médio, deveriam ser organizados em módulos, cada um deles dando direito a um certificado de qualificação profissional, na suposição de que a organização modular corresponderia às profissões/ocupações existentes no mercado de trabalho (Cunha, 2001, p. 98).

Mais tarde, contrariando a concepção original do decreto, o Conselho Nacional da Educação estabeleceu que o certificado de técnico somente seria outorgado aos egressos dos cursos técnicos que também tivessem concluído o ensino médio. Ficou excluída, portanto, a possibilidade de o certificado ser concedido a quem somente acumulasse os módulos correspondentes a uma especialidade técnica. Em contrapartida, a tentativa de cisão entre a educação geral-propedêutica e a educação técnico-profissional foi atenuada por esta exigência de conclusão do ensino de nível médio pelos alunos do ensino técnico.

A resolução do Conselho Nacional da Educação, que estabeleceu as diretrizes curriculares do ensino médio, abriu a possibilidade de as escolas incluírem conteúdos profissionalizantes (25\% das disciplinas), que 
poderiam ser incorporados como créditos válidos para a integralização de um curso técnico.

Sendo assim, a certificação educacional das áreas profissionais existe apenas no ensino médio técnico e no ensino superior. As políticas de educação desenvolvidas pelo Governo Fernando Henrique Cardoso, tanto as realizadas pelo Ministério da Educação (MEC) quanto as implementadas pelo Ministério do Trabalho e do Emprego (MTE), não propuseram mecanismos para reconhecer conhecimentos dos milhares de jovens e adultos que não concluíram o ensino fundamental e/ou apresentam defasagem idade/escolaridade, e que são portadores de experiências de trabalho, seja para a continuidade de estudos, seja para a qualificação e requalificação profissionais.

O MEC priorizou o ensino fundamental para os jovens de 7 a 14 anos, objeto do Fundo de Manutenção e Desenvolvimento do Ensino Fundamental e de Valorização do Magistério (FUNDEF), deixando em plano secundário a modalidade educação de jovens e adultos (EJA) (não contemplada pelo Fundo), destinada aos maiores de 14 anos, que constituíram justamente o público-alvo dos programas que integravam o Plano Nacional de Formação e Desenvolvimento Profissional (PLANFOR) ${ }^{2}$ - os cursos profissionais básicos, segundo a denominação do Decreto n. 2.208/97.

No âmbito das políticas de formação profissional do MTE - que a Secretaria de Desenvolvimento e Formação Profissional (SEFOR) insistia em chamar de "educação profissional"3 - também ocorreram incongruências, pois os programas de qualificação profissional não pressupunham a recuperação da escolaridade nem pretendiam a oferta de cursos organizados como itinerários ocupacionais, em consonância com a nova Classificação Brasileira de Ocupaçôes (Св), ${ }^{4}$ e validados por meio de certificados. Havia (e ainda há), portanto, um vazio normativo no que se refere à certificação.

Se, no campo da educação, o debate concentrou-se na perspectiva do reconhecimento de saberes e habilidades adquiridos ao longo da vida pelos trabalhadores para fins de prosseguimento ou conclusão dos estudos e inserção profissional, no campo das relações de trabalho, tratou-se de criar processos certificadores que dinamizassem as novas formas de gestão e de organização dos processos produtivos (Fidalgo, 2003, p. 134).

É importante mencionar que, desde a década de 1980, o Centro Interamericano de Investigación y Documentación sobre Formación Profesional (CINTERFOR-OIT) (Mertens, 1996) realizou inúmeros estudos 
Educação, formação profissional e certificação de conhecimentos...

sobre Certificação Ocupacional visando a delinear uma política para a América Latina a respeito da matéria. Na década de 1990, a denominação do tema direcionou-se para as chamadas "competências laborais" (Vargas Zúñiga, 2002). A difusão, no comércio internacional, das exigências de normas ISO, como a série ISO 9000 (qualidade) e a ISO 14000 (ambiental), implicou o desenvolvimento de ações no sentido de vincular reconhecimento/certificação de conhecimentos dos trabalhadores à certificação de produtos e processos de trabalho.

No Brasil, no âmbito das políticas de qualidade e produtividade, a Lei Federal n. 9.933, de 1999, dispôs sobre as atribuições do Conselho Nacional de Metrologia e Qualidade Industrial (CONMETRO) e do Instituto Nacional de Metrologia, Normalização e Qualidade Industrial (InMETRO), autarquia vinculada ao Ministério do Desenvolvimento, Indústria e Comércio Exterior, e criada, em 1973, para conceder a marca de conformidade aos produtos, processos e serviços. Nos anos de 1990, como agora, diversos órgãos praticavam a atividade de certificação de produtos e de ocupaçôes fora do âmbito do governo. De acordo com o Decreto n. 4.630, de 21 de março de 2003, que aprova a estrutura regimental do INMETRo como órgão executivo do Sistema Nacional de Metrologia, Normalização e Qualidade Industrial (SINMETRO), é sua finalidade "coordenar, no âmbito do SINMETRO, a certificação compulsória e voluntária de produtos, de processos, de serviços e a certificação voluntária de pessoas" (Anexo I, cap. I, inciso VIII. Grifos nossos).

Esse dispositivo legal, segundo algumas interpretações, poderia mudar os rumos da discussão existente, pois vincularia a "certificação das pessoas" à certificação de produtos e processos, na medida em que delega ao INMETRO a atribuição de credenciar instituições para realizar certificação profissional. Ao mesmo tempo, delega a elaboração das normas de certificação a um organismo privado, a Associação Brasileira de Normas Técnicas (ABNT).

Além dos organismos certificadores credenciados pelo INMETRO Fundação Brasileira de Tecnologia da Soldagem (FBTS); Associação Brasileira de Ensaios Não-Destrutivos (ABENDE) - certificação de inspetores de ensaios não-destrutivos para ensaio visual, líquido penetrante, partículas magnéticas, ultra-som, ensaios radiográficos/raios gama e raio-X e correntes parasitas; Centro para Inovação e Competitividade (CIC) - certificação de auditores de sistema de qualidade e de auditores de gestão ambiental -, outras instituições atuam no âmbito da certificação profissional. Entre 
elas o Instituto Brasileiro de Certificação de Profissionais Financeiros (IBCPF) e FIPECAFI, da USP (certificação de profissionais que trabalham na venda de produtos financeiros); Associação Brasileira de Manutenção (ABRAMAN) e Serviço Nacional de Aprendizagem (SENAI-SP) (certificação de profissionais na área de manutenção de máquinas); ASE - associação privada norte-americana, em parceria com o SENAI-SP (certificação de profissionais mecânicos na área automotiva); Instituto de Hospitalidade (IH)/ Fundação Odebrechet (certificação de profissionais nas áreas de hotelaria e turismo).

Experiências ${ }^{5}$ como as da PETROBRÁs, da ABRAMAN e da FBTS desenvolvem um entendimento comum de conceitos, como o de qualificação: "demonstração de aptidão física, conhecimento, habilidade, treinamento e experiência requeridos para executar adequadamente atividades estabelecidas"; e o de certificação: "procedimentos que conduzem ao testemunho escrito na qualificação do nível de competência de um indivíduo, em uma dada atividade do setor industrial" (conforme as normas ISO 9712, EN 473, ABENDE NA - 001) (Lopes Neto, 2003, p. 139).

É possível notar, portanto, que houve, na última década, uma ofensiva do empresariado no sentido de criar um sistema de certificação que transferisse a responsabilidade do Estado para o setor privado e excluísse a participação negociada com a representação dos trabalhadores. Como resultado, tais políticas de certificação realizam-se hoje de forma isolada, desvinculadas das políticas de educação profissional e de certificação de escolaridade.

No Governo Fernando Henrique Cardoso, o MEC e o MTE desenvolveram algumas iniciativas para a criação de mecanismos de certificação, que, entretanto, não resultaram em medidas concretas. $\mathrm{O}$ MEC produziu três documentos referenciais sobre certificação. O primeiro é o Sistema Nacional de Certificação Profissional baseada em Competências. Versão preliminar - fevereiro de 2000, e o segundo, o Subsistema de Avaliação e Certificação Profissional baseada em Competências - SAC - outubro de 2000. O terceiro documento, "Organização de um Sistema Nacional de Certificação baseada em Competências - SNCPC", foi enviado ao Conselho Nacional de Educação (CNE), em novembro de 2002, ${ }^{6}$ no estertor da gestão tucana. Apesar de originário do MEC, seu propósito maior consistiu em dar cobertura legal às atividades de certificação profissional realizadas fora do âmbito do MEC. Com essa perspectiva, propóe separar, e não apenas distinguir, a certificação escolar (de conhecimentos) da 
Educação, formação profissional e certificação de conhecimentos...

certificação profissional, entendida como certificação da pessoa (desempenho), e é omisso com relação à certificação de conhecimentos para fins de continuidade de estudos (Moraes et al., 2002).

O MTE, por sua vez, em parceria com a OIT, desenvolveu entre 1997 e 2001, o projeto CERT/DIV - SEFOR/MTE-OIT Avanço Conceitual e Metodológico da Formação Profissional no Campo da Diversidade no Trabalho e na Certificação Profissional, iniciado com o Seminário Certificação Ocupacional (de Competências?) e Eqüidade (11 e 12 de dezembro, 1997). ${ }^{7}$ Durante mais de quatro anos, foram realizados seminários e reuniōes com a participação de responsáveis por experiências de certificação, de sindicalistas, gestores do "Sistema S", especialistas e consultores nacionais e internacionais. Ao ser dado como concluído, em maio de 2001, o projeto não havia promovido nenhum tipo de negociação entre representantes sindicais e empresariais, ou mantido qualquer relação com a elaboração da nova CBO, apresentada em outubro de 2002. E, sobretudo, não chegou a interferir na nomenclatura e na possível certificação dos cursos do PLANFOR, o mais abrangente programa governamental de formação profissional que já existiu no país. Os certificados de freqüência e aproveitamento continuaram a não ter nenhum tipo de reconhecimento legal.

Objetivando intervir nesse quadro político e social complexo, em consonância com o Plano Plurianual 2004-2007 do Governo Lula, a "política pública de qualificação social e profissional” do MTE propõe substituir a política neoconservadora ou neoliberal do governo passado, direcionada pelo "modelo das competências", e define a qualificação como direito social dos trabalhadores brasileiros, cuja universalização pressupõe o atendimento dos segmentos considerados mais vulneráveis econômica e socialmente, os que apresentam maior dificuldade de inserção no mercado de trabalho, que têm sido alvo de processos de exclusão e discriminação sociais - como as de gênero e etnia, além das geracionais, e de pessoas portadoras de necessidades especiais (Plano Nacional de Qualificação [PNQ-MTE], 2003-2004)

O Plano Nacional de Qualificação (PNQ), 2003-2004, coordenado pelo Departamento de Qualificação (DEQ), com a perspectiva de integrar trabalho, educação e desenvolvimento, propõe articular-se com outras políticas públicas de educação e de geração de trabalho e renda. Nessa direção, visa a contribuir para a integração e a consolidação do Sistema Nacional de Formação Profissional, articulado ao Sistema Público de Emprego e ao Sistema Nacional de Educação. 
No campo da educação escolar, o movimento de revogação do Decreto n. 2.208/97 e a normalização da integração da educação profissional técnica de nível médio ao ensino médio, nos termos do artigo 36 da LDB, pretenderam restabelecer parte do conteúdo do projeto original da Câmara dos Deputados. ${ }^{8} \mathrm{O}$ então Substitutivo Jorge Hage previa que o ensino médio, "mediante ampliação da sua duração e da carga horária global”, poderia incluir objetivos adicionais de educação profissional nas modalidades Normal e Técnica, as quais poderiam ser oferecidas pela instituições de ensino técnico em todo o país. ${ }^{9}$ Ou seja, apesar das contradições que possam ser atribuídas à sua emissão, o Decreto n. 5.154, de 2004, que revogou o Decreto n. 2.208, de 1997, objetiva resgatar as bases unitárias do ensino médio, com o fim de adequá-lo à diversidade própria da realidade brasileira, propiciando a ampliação de seus objetivos, a formação específica para o exercício de profissões técnicas. $\mathrm{O}$ novo decreto tenta restabelecer as condições jurídicas e institucionais que se queria assegurar na disputa da LDB na década de 1980. Mas, como ressaltam Frigotto et al. (2005, p. 10), daqui para a frente, "dependendo do sentido em que se desenvolva a disputa política e teórica, o 'desempate' entre as forças progressistas e conservadoras poderá conduzir para a superação do dualismo na educação brasileira ou consolidá-lo definitivamente". A este respeito, é importante assinalar que as Diretrizes Curriculares Nacionais para o Ensino Médio (Parecer CEB/CNE n. 15/98) e as Diretrizes Curriculares para a Educação Profissional de Nível Técnico (Parecer CEB/CNE n. 16/99), que consolidaram as orientações da política pedagógica imposta pelo Decreto n. 2.208, disseminando o modelo da competência na conformação curricular desses níveis e modalidades de ensino, continuam a nortear a organização da educação brasileira.

As considerações aqui apresentadas permitem afirmar que uma política de certificação profissional expressa, necessariamente, determinada concepção de educação e de formação profissional, a qual, por sua vez, informa a organização do ensino, no país, e condiciona sua relação com o trabalho e a economia. Nessa perspectiva, em face do contexto institucional herdado e das mudanças anunciadas pelo novo governo republicano no campo das políticas de educação e do trabalho, faz-se necessário refletir sobre os desafios presentes na construção de um sistema nacional de certificação profissional que atenda ao conjunto das demandas sociais e não apenas aos interesses de um único segmento social. 
Educação, formação profissional e certificação de conhecimentos...

Os principais desafios para a organização de uma política pública de certificação profissional

\section{Formação e emprego: novas exigências em um contexto de mudanças}

\section{$O$ direito à formação e à certificação}

As sociedades industriais, em todo o mundo capitalista, têm sido confrontadas por crescentes desafios econômicos, sociais e culturais herdados de longos períodos de crise. $\mathrm{O}$ vasto movimento de modernização organizacional e técnica das empresas, dos diferentes setores econômicos, engajadas na competição internacional, vem acompanhado da transformação das identidades profissionais, individuais e coletivas, da construção de "novas competências", do aumento persistente do desemprego, da precarização/informalização do trabalho e, portanto, da exclusão social.

As mudanças afetam, de forma geral e de diferentes maneiras, o conjunto dos trabalhadores, independente de sexo, idade e escolarização, mas atingem com maior intensidade os jovens em busca do primeiro emprego, as mulheres e aqueles de maior idade, menos qualificados e escolarizados, condenados ao desemprego permanente ou de "longa duração".

Nessa conjuntura, a educação e a formação profissional constituem algumas das principais medidas destinadas, em um primeiro momento, a combater as desigualdades entre empresas, produzidas pela competitividade econômica, por meio da adaptação dos trabalhadores às mudanças técnicas e às condiçôes de trabalho; e, em momento posterior, ao atendimento de categorias e grupos de trabalhadores ameaçados pela desqualificação profissional e pelo desemprego. As medidas planejadas nos diferentes países afirmavam existir diferenças entre as capacidades dos trabalhadores - adquiridas por meio da escolarização, formação profissional e/ou experiência no local de trabalho - e as competências consideradas necessárias pela introdução das novas tecnologias, e definiam a formação profissional como meio de atenuar os desequilíbrios entre as "qualificaçōes adquiridas" e as "qualificaçōes requisitadas", de ajustar as formaçōes à evolução do emprego (Dubar, 1996, p. 101).

Essa estratégia da "adequação formação-emprego", defendida pelas abordagens econômicas neoclássicas, marginalistas, mostrou-se incapaz de 
resolver os problemas da inserção profissional, do movimento das qualificações, ou aqueles relacionados às inovaçõos tecnológicas. Ao contrário do que propõe este receituário econômico, os programas de formação que objetivam garantir "empregabilidade", ${ }^{10}$ isto é, possibilitar, a cada um, o acréscimo individual de "capital humano" 11 para sua adaptação às novas condiçôes de trabalho e/ou para o sucesso da empresa, ignoram os processos sociais complexos subjacentes às mudanças em curso.

Em primeiro lugar, a relação entre educação e trabalho, formação e emprego está longe de ser explicada por relaçôes causais, de ordem individual. A questão do desemprego é determinada por um conjunto de fatores de ordem macroeconômica, para além da educação profissional (Hirata, 1999, p. 13). Dito de outra maneira: não se pode perder de vista que educação/formação não gera emprego, que as formas de organização do trabalho, as políticas de emprego e de salário são constitutivas da relação capital/trabalho, e, portanto, inseparáveis da dinâmica da acumulação. Ao mesmo tempo, é preciso salientar que as atuais mudanças na configuração do mercado de trabalho fazem com que a formação desempenhe papel mais ativo na regulação do acesso ao trabalho/emprego e às mobilidades profissionais posteriores, o que confere maior importância às políticas/instituições de formação no sentido de contribuírem para diminuir os riscos de exclusão social (Moraes, 1997).

Nessa perspectiva, tanto o acesso ao trabalho como o acesso à educação escolar e à formação profissional constituem direitos sociais. A geração de trabalho/emprego e a expansão qualitativa e quantitativa da educação apresentam-se como exigências para a ampliação dos direitos de cidadania, como pressuposto à implantação e consolidação do processo democrático.

Em decorrência, as políticas de formação devem estar integradas ao conjunto das políticas públicas voltadas para o desenvolvimento econômico e social do país, devendo ser garantidas, ao longo da vida, e em bases contínuas, a todas as categorias de trabalhadores, empregados e desempregados. Mais precisamente: constitui urgente necessidade uma política pública de formação profissional, como parte do sistema público de emprego, trabalho e renda, que inclua seguro-desemprego, (re)qualificação e direito ao trabalho (com foco no re-emprego).

Em segundo lugar, acompanhando os processos de reconversão produtiva, o discurso da competência, que tem origem no mundo dos ne- 
Educação, formação profissional e certificação de conhecimentos...

gócios e não no meio educacional, foi introduzido no Brasil e em alguns países da América Latina pelos empresários e também pelos governos, estimulados pelos organismos multilaterais. O processo de institucionalização ${ }^{12}$ da noção de competência em nosso país, que lhe confere caráter oficial, realizou-se principalmente mediante as reformas educacionais promovidas, pelo governo anterior, na Educação Básica, Profissional e Superior, e na Classificação Brasileira das Ocupações (Сво).

A noção de competência é ordenadora - segundo a legislação educacional - da organização curricular e de práticas pedagógicas do ensino técnico profissional (Decreto n. 2.208/97; Pareceres CNE/CEB n. 17/97, n. 16/99, Resolução CNE/CEB n. 4/99). No discurso legal, competência é definida como "a capacidade de mobilizar, articular e colocar em ação conhecimentos, habilidades e valores necessários para o desempenho eficiente e eficaz de atividades requeridas pela natureza do trabalho" (artigo $6^{\circ}$ da Resolução CNE/CEB n. 4/99, e item 6.3 do Parecer n. 16/99).

O MTE também incorporou, no governo anterior, o conceito de competência, e as resoluções orientadoras do PLANFOR determinavam que cada programa de qualificação profissional oferecesse, em alguma medida, habilidades básicas, específicas e de gestão. A soma dessas habilidades permitiria o desenvolvimento das chamadas competências.

O mencionado documento, colocado em discussão no Conselho Nacional de Educação (CNE), sobre a criação de um Sistema Nacional de Certificação Profissional baseada em Competências, é coerente com a visão predominante no último período. No artigo $4^{\circ}$, item III, afirma que um dos objetivos centrais da certificação é "propiciar melhores indicadores aos sistemas educacionais para orientar a organização curricular de seus cursos e sua articulação com o sistema produtivo".

Uma das principais questóes no debate atual acerca do tema consiste, portanto, em se a certificação profissional deve ser baseada em competências. $\mathrm{O}$ processo de globalização econômica/financeira e as grandes inovações tecnológicas e organizacionais introduzidas no trabalho têm promovido mudanças nos perfis de qualificação profissional dos trabalhadores e incidido sobre sua educação/formação. A noção de competência, que pretende substituir o conceito usual de qualificação, surge para designar os novos requisitos exigidos pelas recentes transformaçóes nos setores produtivos, no novo paradigma organizacional da produção flexível, com o intuito de substituir a noção de qualificação, afeita ao "antigo" paradigma taylorista. 
Tanto o conceito de competência como o de qualificação são resultado, em determinado contexto histórico, da correlação das forças sociais. A noção de competência, apesar de imprecisa e fluida, converge em suas diferentes versōes para o significado de performance, de desempenho (verificável) em situação de trabalho, independente da forma de aquisiçāo dos conhecimentos pelo trabalhador. Ao contrário da qualificação, fundamentada no conhecimento e em sua relação com a execução do trabalho, e na negociação entre patrões e empregados (correspondência entre formação/carreira/remuneração), as competências, por serem definidas muito mais em razão de critérios ligados ao posto de trabalho do que em termos de conhecimentos, tendem a substituir os processos coletivos de negociação pelo predomínio dos empregadores na definiçāo das normas de competência, a conduzir a uma crescente individualização na apreciação dos assalariados.

Nas diferentes formulações da noção de competência está implícito o objetivo de mobilizar o "saber tácito" dos trabalhadores. Trata-se de formalizar competências "que estão muito mais no nível da subjetividade/intersubjetividade do trabalhador do que as qualificaçôes anteriormente prescritas" (Deluiz, s/d., p. 3) ${ }^{13}$ A organização taylorista do trabalho, ao separar planejamento e execução, ao supor que o saber era (e continua sendo) monopólio dos administradores, engenheiros e chefes, minimizou a capacidade de o trabalhador direto analisar o processo de trabalho e resolver problemas. Ao "legalizar" o "saber tácito" e ao tentar potencializar as possibilidades que a "colaboração" do trabalhador pode trazer para a produtividade da empresa, os estrategistas empresariais vêm buscando no conceito de competência a ferramenta capaz de englobar analiticamente essa "outra dimensão" do trabalhador, e, também, de legitimar ideologicamente sua reapropriação pela empresa.

A substituição das "qualificaçôes" pelas "competências" visa a eliminar os antigos perfis profissionais ligados aos "postos de trabalho" (e, ao mesmo tempo, na maioria das vezes, os direitos a eles vinculados), substituindo-os por outros baseados na "polivalência". No entanto, sob tal denominação abrigam-se formas muito diferenciadas de trabalho: desde situaçôes em que há o predomínio do trabalho enriquecido, com certo grau de autonomia, até outras em que o taylorismo exacerbado continua a presidir a organização do trabalho, fazendo com que o trabalhador - responsável pela execução de várias tarefas - tenha o seu ritmo de trabalho intensificado etc. 
Educação, formação profissional e certificação de conhecimentos...

Interessa ressaltar que para os estrategistas dos setores empresariais, particularmente os dos setores "dinâmicos", o conteúdo do trabalho tem se alterado e continua sofrendo mutaçôes, e, em conseqüência, está em questão "o que" deve ser objeto de certificação profissional. Ao mesmo tempo que se discute um sistema de certificação, também está em debate, e é objeto de polêmica, o próprio conteúdo do que será certificado. ${ }^{14}$

No campo da educação escolar, observa-se a passagem do ensino centrado nos saberes disciplinares a um ensino definido para produzir competências verificáveis em situações e trabalhos específicos (Tanguy, 2000, p. 169). Nessa direção, o Decreto n. 2.208/97, que reformou o ensino técnico, assim como o documento do MEC/CNE (1999), "Diretrizes Curriculares Nacionais para a Educação Profissional de Nível Técnico" (p. 18-19), propõem ajustar as escolas ao mercado organizando os currículos de ensino, de forma modular, tendo como parâmetros o perfil ocupacional e as demandas (competências) do mercado de trabalho - e não mais "currículos montados a partir de disciplinas acadêmicas (...)", na expressão de um ex-consultor ${ }^{15}$ do BID e do MTE.

Dessa maneira, por meio do modelo das competências, a política educacional estabeleceu uma relação direta e subordinada da formação escolar ao sistema produtivo. A adaptação das grades curriculares às mudanças no conteúdo do trabalho, quando as profissóes tendem a desaparecer e a se transformar, tem um pressuposto: o trabalhador terá de se reciclar permanentemente. Em outras palavras: a montagem dos itinerários ocupacionais, ao procurar atender as demandas imediatas e pontuais das empresas, tem levado a formações adaptativas/instrumentais às mudanças, perdendo-se de vista os objetivos declarados do aprendizado teórico mais amplo e integrado dos fundamentos científicos e tecnológicos indispensáveis à formação do trabalhador polivalente e flexível (Moraes, 2002, p. 52).

No atual governo, são outras as orientações apresentadas no PNQ 2003 do MTE e nos documentos produzidos pela Secretaria de Educação Profissional e Tecnológica (SETEC/MEC) como subsídios à elaboração do anteprojeto de Lei da Educação Profissional e Tecnológica, que substituirá o Decreto n. 5.154 de 2004. ${ }^{16}$

O MTE parte da concepção de qualificação "como uma relação social complexa e multidimensional que articula, através de processos individuais e coletivos, trabalho e educação". Para os(as) trabalhadores(as) 
"significa, ao mesmo tempo, maior autonomia do trabalho e aumento do valor de uso da sua força de trabalho e do seu valor de troca no mercado de trabalho". Para os empregadores, "maior possibilidade de aproveitamento da força de trabalho no tempo, traduzido pelo aumento da produtividade e da qualidade". Dessa maneira, a qualificação, como toda a relação social, apresenta-se como espaço de conflito, de disputa entre sujeitos sociais portadores de interesses diferenciados. $\mathrm{O}$ papel do Estado democrático é "o de estabelecer regulações, garantindo o amplo debate das diversas concepções em conflito". Nessa perspectiva, a certificação, na qualidade de uma das políticas públicas de qualificação, objeto de regulação pelo Estado, é entendida como "o reconhecimento social dos conhecimentos, habilidades e competências construídos na vida, no trabalho e nas lutas sociais do(a) trabalhador(a)" (Lima, 2003).

Para o MEC, "a certificação de conhecimentos e de saberes é mais abrangente, bem como extrapola o âmbito dos interesses mais específicos da empresa que busca, com prioridade, o reconhecimento do padrão de qualidade de seus produtos. Ao trabalhador também pode interessar certificar certos conhecimentos, saberes e habilidades ou competências para fins de preparar-se para o mercado de trabalho. É preciso destacar que as competências se reduzem a uma parte dos atributos do trabalhador, não incluindo dimensões culturais e cognitivas fundamentais à avaliação das potencialidades dos sujeitos”. Propõe, neste sentido, a análise crítica do "uso generalizado do modelo da competência na educação, que introduz um viés na compreensão do significado da educação e a certificação profissional e de conhecimentos porque reduz um processo complexo de formação humana a um dos seus aspectos específicos, ao desempenho de tarefas úteis e práticas". E, conclui, "o conceito de competência, anteriormente referido, evidentemente não se aplica às novas dimensões da educação profissional e tecnológica, marcada pelos fundamentos científicotecnológicos, bem como histórico-sociais, cujos parâmetros balizaram o longo percurso para a construção destas políticas públicas".

Nessa direção, torna-se indispensável rever as Diretrizes Curriculares Nacionais do Ensino Médio e da Educação Profissional Técnica, e rejeitar a concepção por elas veiculadas de que a efetividade da política de formação profissional depende de sua ligação direta com o sistema produtivo. Estudos, como os realizados por Tanguy (1994), na França, e diagnósticos construídos na Espanha, pelo CIREM (Homs, 2003), assim como as experiências desenvolvidas em regiōes da Itália como a Emília- 
Educação, formação profissional e certificação de conhecimentos...

Romagna ${ }^{17}$ e a Toscana, ${ }^{18}$ por exemplo, indicam que as diferentes modalidades de formação profissional estreitamente dependentes do mercado de trabalho não têm resistido às mudanças impostas pela organização do trabalho, ao passo que aquelas que não se subordinaram ao mercado têm tido a capacidade de traduzir as novas demandas em sua própria lógica, fornecendo-lhes respostas gerais, integradas em um projeto social aberto ao futuro (Moraes, 1999, p. 27).

Sob esse aspecto e no que diz respeito à concepção de formação profissional e de sua relação com as mudanças no mundo do trabalho, cabe enfatizar que, longe de qualquer determinismo econômico ou tecnológico, são as opções organizativas que definem a qualificação do posto de trabalho e a autonomia do trabalhador - o que tem importantes consequiências para a adoção das políticas empresariais, de emprego e de formação. As políticas de educação e formação profissional não podem ser consideradas por mais tempo as respostas às necessidades do sistema produtivo, como se tais necessidades fossem efeito inevitável das mudanças tecnológicas ou competência exclusiva dos empregadores. Ao contrário, devem ser vistas como estratégias com conseqüências no campo da produção, isto é, como opções formativas vinculadas a opções sobre o emprego e a organização de trabalho, que derivam destas e são, ao mesmo tempo, uns dos instrumentos de sua materialização (Enguita, 1992, p. 35). Nessas circunstâncias, os agentes sociais e os poderes públicos não podem permanecer neutros em face das diferentes opções organizativas, já que estas afetam a produtividade das empresas e, portanto, da economia em geral, e as condiçôes de trabalho.

No Brasil, certos instrumentos podem favorecer a adoção de modelos organizacionais no trabalho de efeitos mais favoráveis em termos econômicos e sociais, como: políticas de geração de emprego, políticas de crédito, políticas fiscais e de negociação social. Constitui uma exigência inadiável o estabelecimento da negociação de toda a inovação tecnológica ou organizacional entre empresa e trabalhadores, o que significa vigência do direito constitucional da negociação coletiva, participação dos sindicatos na formulação e no gerenciamento das formaçôes profissionais desenvolvidas nas empresas, e organização de comissóes paritárias para propor e acompanhar essas iniciativas ou de outros processos educacionais em curso nos locais de trabalho. (Moraes, 1999, p. 27)

Em terceiro lugar, no Brasil, a formação profissional envolve vários organismos, públicos e privados, e diz respeito a um tipo de demanda da qual participam sujeitos sociais diferenciados, que ocupam posições 
desiguais na complexa trama da vida em sociedade. Historicamente, a iniciativa privada - empresas e agências empresariais de formação profissional, como o sistema "S" - tem papel significativo nessa correlação de forças, e está, hoje, ampliando a importância e a abrangência de sua participação (direta) no desenvolvimento da formação dos trabalhadores ativos, assumindo, cada vez mais, espaços antes ocupados por outras instituições.

Além disso, as conseqüências das mudanças nas relações de trabalho sobre o perfil de qualificação e sobre a formação profissional não têm a mesma extensão, o mesmo significado nem o mesmo alcance para os homens e as mulheres. As condiçôes de trabalho/emprego e as formas e inserção nas atividades variam segundo o sexo da mão-de-obra, configurando significativas desigualdades entre os sexos. $\mathrm{O}$ processo de precarização da força de trabalho reforçou a polarização das qualificações segundo o sexo, na qual as mulheres ocupam os postos paradoxalmente empobrecidos, de menor qualificação. O enriquecimento do trabalho e a formação qualificada, quando ocorrem, dizem respeito ao trabalhador do sexo masculino (Hirata, 1998, p. 17).

A organização atual da formação, apresentando os mesmos padrōes de distorção do mercado, ${ }^{19}$ tem propiciado maior acesso aos indivíduos empregados e/ou mais escolarizados e qualificados, mesmo nos programas governamentais destinados aos trabalhadores em situação de risco social. Como conseqüência, tem contribuído para aumentar a segmentação do mercado de trabalho e promover uma nova hierarquização da força de trabalho.

Nessas circunstâncias, como democratizar o acesso à formação profissional? No que diz respeito às empresas e agências empresariais, cujas açôes educativas estão destinadas a trabalhadores empregados, a prioridade atribuída à competitividade incluiria a luta contra a exclusão? Nesse caso, formação/treinamento profissional parece ser o meio de manter, em função das necessidades da empresa, as qualificações daqueles que já as possuem.

A democratização da oferta de formação profissional, isto é, o direito à formação, concernente ao conjunto da população ativa - àqueles que exercem atividade de trabalho e àqueles que estão privados dela -, deve ser garantida pelo Estado, e só pode ocorrer se acompanhada de uma política de expansão e melhoria da qualidade do ensino básico. A 
Educação, formação profissional e certificação de conhecimentos...

formulação de políticas públicas de educação e formação profissional deve responder às necessidades dos trabalhadores brasileiros, jovens e adultos, que apresentam, em sua maioria, baixos índices de escolaridade formal. A entrada precoce na vida ativa (antes de 17 anos) de $85 \%$ da população trabalhadora (PEA) resultou, freqüentemente, na impossibilidade de prosseguimento dos estudos: 57,64\% dos brasileiros com 15 anos ou mais de idade, aproximadamente 69 milhões e 700 mil pessoas, não têm escolaridade de nível fundamental concluída (Pesquisa Nacional por Amostra de Domicílios [PNAD], 2001). As políticas de educação profissional necessitam priorizar a oferta da formação profissional articulada à da educação básica, constituindo-a em ocasião privilegiada para essa população, desprovida do direito à escolaridade, obter a formação geral e, ao mesmo tempo, adquirir uma qualificação.

A recuperação da escolaridade da população exige que se priorize a organização da educação de jovens e adultos (EJA), cujos conteúdos e métodos de ensino devem adequar-se às realidades profissionais e sociais dos trabalhadores. Faz-se necessário planejar a organização de cursos durante o tempo de trabalho. Ou seja, as empresas devem proporcionar anualmente a seus trabalhadores um número de horas da jornada de trabalho para educação/formação profissional. Esse número de horas deve ser regulamentado por lei, como direito a uma formação remunerada pelo empregador, reivindicação que raramente está presente nas orientações das políticas escolares.

Em síntese, a integração da formação profissional ao sistema nacional de educação é hoje determinante para a progressão escolar e o desenvolvimento profissional dos trabalhadores. Um dos objetivos mais urgentes no planejamento da formação e da certificação profissional, condição para sua democratização, consiste no reconhecimento dos saberes em todo o sistema educacional. É preciso regulamentar a certificação de conhecimentos nesta modalidade de formação: a educação profissional de nível básico, que, como já foi observado, permanece - como cursos livres, não sujeitos à regulamentação do MEC - sem qualquer tipo de orientação normativa que permita a validação desses conhecimentos, seja para a classificação funcional da ocupação, seja para posterior aproveitamento dos estudos.

A organização de uma política pública nacional de certificação profissional seria uma maneira de viabilizar aos trabalhadores a possibilidade de gerir seu itinerário formativo, propiciando-lhes certificados com vali- 
dade no mercado de trabalho e, também, "intercambiáveis aos títulos e diplomas escolares" (Fidalgo, 2003, p. 134).

A certificação profissional representa, para os trabalhadores, a eliminação de barreiras tanto para a inserção e progressão profissional quanto para o prosseguimento dos estudos. Em contrapartida, para os empregadores, poderia significar a melhora nas condiçóes gerais de uso da força de trabalho. Uma formação profissional certificada sistematicamente facilitaria o seu reconhecimento no mercado de trabalho e motivaria os trabalhadores para que a realizassem (Homs, 2003, p. 8).

Em quarto lugar, reconhecimento/validação das qualificações constitui um dos grandes desafios a serem enfrentados. A construção de sistemas de classificação das ocupações e de certificação profissional nos diferentes países e sua harmonização aparecem como exigência fundamental para a dinamização de um mercado de trabalho ativo. Uma política que favoreça tal processo constitui não só um instrumento de dinamização da economia como também elemento de proteção dos trabalhadores, de sua qualificação e das definições salariais correspondentes.

A validação da experiência profissional e das ações da formação deve obter o seu reconhecimento no emprego, na classificação das ocupações, no salário e na continuidade dos estudos. Tal situação coloca abertamente a questão da participação dos agentes sociais, dos representantes do Estado, dos trabalhadores e empresários, na gestão/promoção da formação e nos processos de certificação profissional.

As especificidades históricas da realidade econômica, política e social de nosso país indicam uma série de dificuldades em transpor as certificaçōes ao mundo do trabalho. Como obter o reconhecimento das certificaçōes pelos empregadores? No Brasil, como se sabe, ao contrário do que ocorreu em países centrais do capitalismo, não se estabeleceram relações de trabalho democráticas - liberdade sindical, negociação coletiva, organização no local de trabalho -, não se instituiu a negociação dos processos de organização do trabalho e da formação.

É necessário, portanto, garantir que a certificação seja o resultado de uma construção coletiva, tornando inadiável o estabelecimento da negociação de toda ação formativa e de certificação entre trabalhadores e empresários. O que significa, como já foi apontado, a organização de comissões paritárias para propor e acompanhar os processos educacionais em curso nos locais de trabalho e o direito constitucional da negociação 
Educação, formação profissional e certificação de conhecimentos...

coletiva, da participação dos sindicatos na formulação e no gerenciamento das formações profissionais desenvolvidas nas empresas. Pressupóe também a criação de espaços institucionais públicos que viabilizem a intervenção dos trabalhadores, empregados e desempregados, no reconhecimento e na construção social das qualificações, ou seja, na definição dos perfis profissionais, dos processos formativos, dos critérios e dos procedimentos de certificação (Moraes, 1999, p. 27). O que for firmado nos acordos coletivos por categorias profissionais dos diferentes setores da economia e das regiões deverá ser - por sua vez - normalizado, impulsionado e garantido via legislação nacional. Em resumo:

- O Sistema de Certificação só apresenta legitimidade social quando construído a partir da negociação entre empresários e trabalhadores e suas representações constituídas. Os países onde os sistemas adquiriram alguma viabilidade e efetividade foram aqueles em que houve processo negociado entre as partes sociais.

- O processo de identificação e validação/certificação das qualificações profissionais características de uma ocupação deve ser público (definição de critérios, metodologia e procedimentos), com o fim de garantir qualidade homogênea aos processos formativos, validade nacional aos certificados e facilitar sua transparência e reconhecimento no mercado de trabalho, e, portanto, na mobilidade profissional dos trabalhadores. A certificação deve ser "objeto de regulação pelo Estado, sendo indelegável este papel” (Lima, 2003). Estando a formação profissional integrada ao sistema nacional de educação, os órgãos expeditores do certificado profissional devem ser o Ministério da Educação e o Ministério do Trabalho.

$O$ conhecimento da realidade do mercado de trabalho: um requisito da formação e da certificação

A organização de uma política pública de formação profissional exige que se conheça a realidade da economia, em seu conjunto, no plano nacional, regional e local. O planejamento da formação - da chamada educação profissional básica e da média - torna necessário conhecer o comportamento do mercado de trabalho - formal e informal - de forma 
antecipada. É preciso conhecer o movimento do emprego/desemprego, as mudanças nas profissóes, no conteúdo das ocupações e a oferta da formação na perspectiva do desenvolvimento dos diferentes setores econômicos (novas tecnologias, inversões, mercados etc.) e do desenvolvimento territorial - nacional/regional/local (cadeias produtivas, acordos e planos de geração de emprego, trabalho e renda etc.).

Um dos principais problemas dos programas atuais de educação/ formação profissional de nível básico, no país, consiste na ausência de um plano de formação continuada que, além de propiciar a recuperação da escolaridade, organize os cursos em itinerários formativos correspondentes às diversas especialidades ou ocupaçóes pertencentes aos diferentes setores da economia e, portanto, em correspondência com a Classificação Brasileira de Ocupações (Сво).

A identificação das possíveis trajetórias ocupacionais e a construção dos itinerários formativos, além de permitir melhor correspondência entre os requisitos demandados nas atividades de trabalho e os perfis construídos no processo educativo, podem dar condições aos trabalhadores de adequar, de acordo com suas possibilidades e condições, o itinerário formativo ao itinerário profissional.

A construção de itinerários de formação é condição fundamental para que os cursos possuam certificação, e, dessa forma, sejam vinculados aos processos regulares de ensino e valorizados no mercado de trabalho. Os diversos cursos desenvolvidos pelos diferentes agentes sociais - municípios, entidades sociais, ONGs, sindicatos e programas orientados pelo MTE - passariam a ter elementos orientadores/normatizadores das suas respectivas nomenclaturas (conteúdo de ensino, duração etc.).

Conforme a concepção de formação profissional defendida pela Central Única dos Trabalhadores (CUT) (Resolução do V Congresso Nacional da CUT/CONCUT, 1994), a organização dos processos formativos não deve constituir-se em mera justaposição de cursos específicos já existentes, "transformados em módulos de grandes cursos". Ao contrário, um plano de formação continuada deve se organizar em módulos seqüenciais, progressivos e flexíveis, estruturados de forma que abarquem vários níveis de conhecimentos - dos básicos e técnicos gerais de uma área até os profissionais mais específicos, incluindo-se aí os saberes mais abrangentes, novos conhecimentos e conceitos relevantes na atualidade, que permitam visão ampla do processo produtivo e possibilitem a inserção/intervenção na sociedade contemporânea. 
Educação, formação profissional e certificação de conhecimentos...

É preciso superar a fragmentação da política educacional herdada do Governo FHC, quando ações do MEC ocorreram completamente separadas das do MTE. As políticas de formação e certificação profissional devem ser iniciativa conjunta dos dois ministérios e estar relacionadas à nova Classificação Brasileira de Ocupações (Сво).

As reformulações curriculares na organização do ensino técnico, promovidas por aquele governo, que se referenciam na Classificação Brasileira de Ocupaçôes (СвО), são ainda incipientes. Além disso, orientamse segundo o "modelo das competências" e seguem os passos do Sistema Nacional de Aprendizagem Industrial (SENAI), utilizando metodologias que só permitem apreender as mudanças nos empregos formais e, de maneira ainda mais restrita, naqueles relacionados a grandes empresas. Se tais metodologias são coerentes com os objetivos e as demandas de uma instituição empresarial, elas não são pertinentes aos propósitos e às demandas sociais que uma política pública deve responder.

A esse respeito, é importante considerar também que, se, por um lado, a diversidade das situaçôes e o crescimento persistente do desemprego têm levado ao reconhecimento social da necessidade da realização de estudos sobre o desempenho do mercado de trabalho, verifica-se, por outro lado, a inadequação dos indicadores existentes, que não podem ser problematizados para sua utilização na formação profissional (Moraes, 2002, p. 221). Observou-se que, independente de sua qualidade, estudos como a Relação Anual de Informaçôes Sociais (RAIS) (ou Cadastro Geral de Empregados e Desempregados - CAGED/MTE) apresentam "um quadro da realidade com linhas grossas demais" para os objetivos pretendidos, isto é, para a formulação das prioridades concretas de qualificação. Além de não trazer informaçōes sobre o setor informal, uma das principais dificuldades diz respeito à apresentação dos dados de forma muito agregada, por setor de atividade - "indústria", "comércio" e "serviços" -, que pouco informam sobre as "ocupaçôes", objeto de nosso interesse (Salm, 1999). Uma outra opção seria a utilização da Pesquisa Nacional por Amostra de Domicílios (PNAD) que apresenta, como vantagens, o fato de ser representativa do estado e, como é domiciliar, de apreender tanto o setor formal como o informal. No entanto, como observam Salm et al. (1999), sua desvantagem consiste em não apresentar informações para cada município.

Nessa medida, torna-se urgente o desenvolvimento de pesquisas e novas metodologias na análise das situações de emprego/desemprego e 
do movimento das ocupaçóes. O que supõe, por sua vez, a existência, no país, de instituiçôes públicas, geridas com a participação dos trabalhadores, que atuem como observatório nacional permanente de situaçôes de emprego e da formação, de maneira que subsidiem a atuação das comissões paritárias setoriais e a elaboração de políticas públicas.

A educação, a formação e a certificação profissional como direito: a importância estratégica da participação social na definiçāo das politicas públicas

A participação de todos os atores sociais envolvidos no campo da certificação profissional é um dos elementos mais importantes para garantir os princípios da legitimidade, confiabilidade, validade e credibilidade dos processos certificadores. Os sindicatos e as organizaçóes empresariais devem assumir papel-chave participando, de forma paritária, junto com as administraçōes públicas, nos espaços institucionais públicos encarregados da criação, gestão e promoção de estruturas formativas de qualidade e dos processos de certificação.

Nos países em que se constituiu o Estado do Bem-Estar Social, onde se desenvolveu o direito coletivo às formaçóes profissionais ligadas às políticas de emprego e de qualificações das empresas, a certificação profissional tem sido fruto da negociação social.

Na Itália, a partir da década de 1970, houve consolidação progressiva e estruturação crescente das negociaçōes sindicais da formação profissional. Este processo passou por diferentes fases: primeiramente, a inclusão do chamado "direito às 150 horas" de formação nos contratos nacionais de trabalho de vários setores (o que, nas regiôes mais industrializadas, significou a eliminação do analfabetismo); em seguida, os acordos entre as centrais de trabalhadores e as organizaçóes empresariais sobre formação profissional nas empresas e nos diferentes setores; e, por fim, a transferência das atribuiçōes de custeio da formação profissional aos governos regionais, com a efetiva participação das partes sociais (sindicatos, centrais de trabalhadores e organizaçōes de representação do empresariado), além da inclusão dos programas de formação profissional nos planos trienais de desenvolvimento econômico e social das regiôes. A recente tentativa de separar o percurso educacional ou a formação geral (liceu) da formação profissional (istruzione professionale), realizada pela "Reforma Moratti" (que leva o nome da atual ministra da Educação), foi rechaçada 
Educação, formação profissional e certificação de conhecimentos...

pela maioria esmagadora dos professores, da intelectualidade e dos sindicatos. Algumas regiões, particularmente a Emilia-Romagna e a Toscana, votaram normas que atenuaram, ou mesmo anularam, os efeitos desarticuladores do ensino não integrado.

$\mathrm{Na}$ França, ${ }^{20}$ os perfis profissionais resultam de acordos entre a representação dos empregadores e a dos empregados dos setores econômicos respectivos; e, em etapa posterior, para elaboração dos currículos escolares ou itinerários formativos correspondentes às novas ocupações, são constituídas instâncias públicas de representação paritária, com a incorporação, ao lado das partes sociais, de representantes de organismos governamentais, como os Ministérios do Trabalho, da Educação e da Ciência e Tecnologia, além de representantes das instituiçôes de educação e formação profissional. Nessa perspectiva, os processos de avaliação e certificação profissional visam a analisar/comparar, a posteriori, se o candidato apresenta o domínio de conhecimentos/habilidades constitutivos de determinado perfil ocupacional/profissional reconhecido socialmente e previamente definido. Tal processo de certificação/validação de conhecimentos profissionais inclui diferentes possibilidades de avaliação que contemplam situações e demandas diversas dos trabalhadores, mas todas elas integradas ao sistema de educação nacional de forma a compatibilizar o reconhecimento das aquisições profissionais com os diplomas correspondentes a determinados níveis escolares e a continuação dos estudos pelos trabalhadores, inclusive no nível superior.

Recentemente, apesar de ainda dominante e freqüente, a certificação realizada a partir da classificação ocupacional definida nas convençôes coletivas convive com outras modalidades de aquisição de diploma profissional que se desenvolveram naquele país. Direcionadas, em geral, aos adultos e aos jovens com dificuldades de inserção no mercado de trabalho, expressam a tendência à individualização crescente no percurso de formação dos trabalhadores e na sua avaliação. Este procedimento se dispõe a validar as aquisições profissionais, isto é, os saberes e as competências adquiridos na experiência de trabalho por intermédio de provas/exames sem que seja necessário passar pela formação.

O processo de certificação de competências para o trabalho é, portanto, definido como resultado de avaliação realizada unicamente por meio de um tipo de procedimento: o exame (em qualquer de suas formas - escrito, oral, "prático"). Em outras palavras: nesse modelo proposto de certificação de competências, ao contrário do outro sistema de 
certificação, o processo de aprendizagem não é considerado central e seu conteúdo não é precisado. Leva-se em conta a capacidade de realizar uma tarefa conforme a norma; e a competência pode ser avaliada na ausência de toda ação formativa ou de escolaridade. Segmento expressivo da representação dos trabalhadores franceses ${ }^{21}$ vem criticando essa modalidade de validação por tentar destruir o conceito de qualificação, reduzir os diplomas a um conglomerado de conhecimentos elementares, fazendo desaparecer a noção de quadros de classificação construídos coletivamente a partir dos níveis de formação profissional. Apontam o enfraquecimento dos processos de negociação, o afastamento do Estado e o peso crescente dos empregadores na apreciação e no reconhecimento das aquisições, cuja única referência é a prática nos ramos profissionais. Enfim, condenam a ruptura da ligação tradicional entre validação e formação, assim como a quebra das regras juridicamente definidas de correspondência entre o diploma escolar e o título/certificado profissional, que teriam por objetivo satisfazer as exigências atuais de flexibilidade no sistema econômico atual (Boudet et al., 1998, p. 47).

A resistência aos procedimentos desse tipo de dispositivo - que exclui os processos de negociação entre as representações das partes sociais e transfere o controle da formação aos empregadores, desestruturando o campo da formação inicial e contínua tal como aconteceu na Inglaterra tem consistido em reivindicar, tanto na França como na Espanha, o fortalecimento da educação escolar (a "formação inicial") e da formação geral no conjunto da formação continuada. Na Espanha, tal como aqui, está presente no debate social a necessidade de garantir a qualidade da formação dos trabalhadores via integração do conjunto da formação profissional continuada à educação nacional (Homs, 2003).

Diante das orientações dispostas pelo governo brasileiro anterior, ainda presentes na legislação educacional, a respeito do desenvolvimento dos processos formativos e da certificação profissional fundamentados no modelo das competências, convém insistir nas mudanças introduzidas por esse modelo, nos países citados, quanto às estratégias empresariais de individualização da formação, em detrimento das necessidades coletivas demarcadas nos processos de negociação com a presença ativa dos interlocutores sociais.

De qualquer maneira, independentemente da terminologia a ser utilizada - competências ou qualificação - o que importa politicamente é atribuir-lhe um conteúdo que responda a necessidades/interesses dos 
Educação, formação profissional e certificação de conhecimentos...

trabalhadores. Nessa perspectiva, como construção social, as qualificações ou as competências devem ser frutos de negociação/consenso social. Os acordos coletivos devem normalizar a classificação profissional, os níveis de competências e os chamados campos de polivalência, e sua relação com os critérios de inserção, promoção/mobilidade profissional e definição salarial.

A formação ao longo da vida só se tornará uma realidade social na medida da participação dos trabalhadores e de seus representantes nas decisões e na gestão das formações que lhes concernem. O sistema de certificação profissional deve se constituir como construção coletiva, viabilizar/promover a participação dos trabalhadores na definição dos perfis profissionais, dos processos formativos, dos critérios e procedimentos da certificação profissional, em síntese, dos níveis profissionais e sua relação salarial.

A forma paritária de representação e ação dos setores sociais na construção da politica pública de certificação profissional

Se a validação e/ou o reconhecimento social das qualificações é o objetivo da constituição de um sistema nacional de certificação, quais seriam as conseqüências, o valor de sua aplicação nas convençôes coletivas e na promoção profissional e salarial dos trabalhadores? As empresas estariam preparadas para reconhecer e incorporar as qualificaçóes e formações certificadas? Este é um ponto a ser discutido entre os agentes sociais, e agrega importância à forma de representação e ação desses agentes na construção desse sistema.

A proposta de organização de uma política nacional de certificação profissional, assim como a construção de sua estrutura de coordenação, seu formato e funcionamento, deve ser elaborada com a participação dos diferentes agentes sociais envolvidos: os representantes dos trabalhadores, dos empregadores e da comunidade educacional, e a administração pública - os órgãos federais das áreas pertinentes, dos Ministérios da Educação, do Trabalho e da Ciência e Tecnologia. ${ }^{22}$

Em termos de contribuição, apresentamos algumas sugestões:

- Constituição de uma estrutura federal de coordenação e de recursos para a formação/certificação profissional, de representação paritária, na qual os agentes sociais, a administração públi- 
ca federal e as estaduais negociem o desenvolvimento de políticas desenhadas, em seus grandes objetivos, para atender as necessidades formativas previamente diagnosticadas e priorizadas.

- Essa estrutura pressupõe a existência de um observatório nacional de situações de trabalho e de formação, também de gestão paritária, responsável pela produção de informações e análises sobre a realidade da economia, das situações de trabalho e da oferta de formação profissional. Tal observatório teria como atribuição subsidiar a estrutura federal no planejamento da educação/formação profissional no país.

- Caberá à estrutura federal coordenar a organização dos Conselhos Consultivos Setoriais, de representação paritária (os representantes dos empregadores, dos trabalhadores, da comunidade educacional, e a administração pública - os órgãos federais das áreas pertinentes, dos Ministérios da Educação, do Trabalho e da Ciência e Tecnologia), para elaboração de processos formativos com base na definição dos novos perfis profissionais/ ocupacionais acordados nas convençóes coletivas das diferentes categorias profissionais.

- No que se refere à exigência de articulação entre certificação profissional e escolarização, levando-se em conta as especificidades/peculiaridades econômicas características das diferentes regiōes do país, seria fundamental a participação da rede federal de escolas técnicas e dos CEFETs, assim como das escolas técnicas estaduais, que, entre outros aspectos, estão localizadas nos diferentes estados e atendem à diversidade regional, como "braços" do MEC no processo da certificação profissional.

- Nessa estrutura, além dos recursos públicos, as empresas devem estar obrigadas a contribuir com o financiamento da formação continuada/aprendizagem.

- Nessa direção, todos os recursos públicos destinados à educação/formação profissional terão gestão pública. No caso do Sistema "S", financiado com recursos públicos e de gestão privada, deverá ser providenciada a gestão pública da instituição, com a participação da representação dos trabalhadores.

Mais do que uma política de governo, faz-se necessária uma política de Estado que enfrente a gigantesca tarefa de eliminar o analfabetis- 
Educação, formação profissional e certificação de conhecimentos...

mo, o analfabetismo funcional, a baixa escolaridade e a ausência de qualificação profissional, principalmente entre os adultos trabalhadores. $\mathrm{O}$ princípio da escola pública unitária, gratuita, laica, de qualidade e de acesso universal deve orientar as ações de integração entre a educação e a formação profissional.

\section{Recebido em junho de 2005 e aprovado em agosto de 2005.}

\section{Notas}

1. Sobre isso, ver Boudet et al., 1998.

2. Ver histórico do antigo PLANFOR, disponível em: <http://www.trabalho.gov.br/temas/ qualprof/Conteúdo/hitórico.asp>.

3. A SEFOR, que ainda naquele governo passou a ser denominada de Secretaria de Políticas Públicas de Emprego (SPPE), foi a gestora do PLANFOR. Uma das metas estabelecidas foi a do “avanço conceitual". Neste percurso, as ações do MTE foram classificadas, conforme o Decreto n. 2208/97, como "educação profissional".

4. A сво consiste na ordenação de várias categorias ocupacionais existentes no mercado de trabalho brasileiro. Origina-se do Cadastro Brasileiro de Ocupações (CIUO) da Organização Internacional do Trabalho (ОIT), de 1968. É um sistema de classificação importante porque é adotado nas atividades de registro do Sistema Nacional de Emprego (SINE), de preenchimento do contrato de trabalho, de levantamento estatístico da RAIS, entre outras atividades. Fidalgo \& Machado, 2000. Ver, também, em http://www.mtecbo.gov.br.

5. O relato dessas experiências pode ser encontrado em Organização Internacional do Trabalho, Certificação de Competências Profissionais, Relato de Algumas Experiências Brasileiras. Brasília: OIT, 2002. Disponível em: <http://www.ilo.org/public/portugue/region/ampro/ brasilia/info/download/index.htm $>$.

6. O documento - Ofício MEc/semtec/Proep n. 2.398 de 4/11/2002 - foi protocolado no Conselho Nacional de Educação em 11/11/2002, e distribuído ao conselheiro Francisco Aparecido Cordão para o fim de relatoria. O parecer desse relator foi, finalmente, encaminhado ao CNE como processo n. 23001.000212-52.

7. Os parênteses e a interrogação fazem parte do título do seminário. A grande "estrela" desse seminário foi o Programa Conocer, do México, que trazia a novidade da Certificação Profissional por Competências. Hoje não é considerado referência por nenhuma das correntes que participam da discussão do tema. Sobre isso, ver http://www.conocer.org.mx.

8. O decreto é um instrumento que normaliza, regulamenta a lei; ele não pode inovar, não pode contrariar a lei. Nessa perspectiva, segundo Frigotto et al. (2005), o Decreto n. 2.208/97 era ilegal ao determinar a separação entre o ensino médio e a educação profissional: "A educação profissional de nível técnico terá organização curricular própria e independente do ensino médio (...)" (Decreto n. 2.208/97, art. 5\%), em confronto com a LDB: "O ensino médio, atendida a formação geral do educando, poderá prepará-lo para o exercício de profissões técnicas" (Lei n. 9.394/96, art. 36, \$2 $2^{\circ}$ ) e "A educação profissional será desenvolvida em articulação com o ensino regular (...)” (art. 40). 
9. No Substitutivo Jorge Hage, a relação entre ensino médio e educação profissional ficou assim definida: "Assegurada aos alunos a integralidade da educação básica, que associa à educação mais geral, nesta etapa, as bases de uma educação tecnológica e politécnica, conforme disposto no artigo 51, o ensino médio poderá, mediante ampliação da sua duração e carga horária global, incluir objetivos adicionais de educação profissional” (Brasil, 1989, art. 50). Sobre isso ver Frigotto \& Ciavatta, 2002, e Frigotto et al., 2005.

10. A respeito da noção de empregabilidade, ver Gentili, 1999.

11. Sobre a Teoria do Capital Humano, ver Frigotto, 1984.

12. A esse respeito, ver Machado (2003).

13. O saber tácito designa o conhecimento implícito e informal, subentendido, resultante da experiência, da história individual ou coletiva dos indivíduos. Os trabalhadores utilizamno, no processo de trabalho, para expressar seu poder sobre ele (Fidalgo \& Machado, 2000, p. 67). A respeito do saber tácito, consultar também Ferretti, 2001.

14. Sobre a questão, consultar o texto de Sebastiāo Lopes Neto \& Gustavo Codas, Sistema nacional baseado em competências: comentário ao documento do MEC, elaborado para efeitos de apresentação das posições da CUT no seminário realizado pelo MEC, em Brasília, em 22/2/2000.

15. Oliveira, "Novos rumos à formação profissional". In: Semana Internacional. FIEMG. Anais, 1995. J.B. Oliveira pertenceu aos quadros técnicos do Banco Mundial, do BID e da OIT, tendo sido secretário-geral do Ministério da Educação por quase um ano, na primeira gestão do ministro Paulo Renato. A esse respeito, ver Cunha, 2001, p. 245.

16. Setec/mec. Proposta em discussão: Políticas públicas para a educação profissional e tecnológica. Brasília, abril/2003.

17. Disponível em: <http://www.regione.emilia-romagna.it/web_gest/giunta/fora.htm>.

18. Disponível em: <http://www.regione.toscana.it>.

19. Segundo dados da Fundação SEADE e do DIEESE, publicados nos Anuário dos Trabalhadores 20002001, em 2001, as taxas de desemprego aberto atingem, em média, 17\% da PEA nas seis regióes metropolitanas, e mais de $50 \%$ dos ocupados encontram-se no mercado informal. As taxas de desemprego entre as mulheres são, em média, quatro pontos porcentuais superiores às dos homens. E, aproximadamente, $50 \%$ dos desempregados são jovens com idade até 24 anos.

20. A França tem uma nova lei oriunda de amplo acordo entre as partes sociais. Sobre isso, ver Gelot (2004). Consultar, também, http://www.travail.gouv.fr/formation.html.

21. A esse respeito, ver Joubier 1997a e $1997 \mathrm{~b}$.

22. Em 2 de setembro de 2003 foi instituído o Grupo de Trabalho Interministerial sobre Qualificação e Educação Profissional (GTi/QEP), pela Secretaria de Políticas Públicas de Emprego (SPPE/MTE) e pela Secretaria de Educação Média e Tecnológica (SEMTEC/MEC), com o objetivo de articular ações e estratégias em áreas de atuação comum aos dois ministérios no campo da qualificação e da educação profissional. Na definição das atribuiçōes do GTI/QEP está a articulação com os organismos e as representações da Sociedade Civil. Ver Portaria Interministerial n. 13, de 2 de setembro de 2003, Diário Oficial da Uniāo.

\section{Referências bibliográficas}

ALEXIM, J.C.; LOPES, C.L. A certificação profissional revisitada. Bole-
tim Técnico do Senac, Rio de Janeiro, v. 29, n. 3, p. 3-15, set./dez. 2003.

Educ. Soc., Campinas, vol. 26, n. 93, p. 1435-1469, Set./Dez. 2005

Disponível em <http://www.cedes.unicamp.br> 
Educação, formação profissional e certificação de conhecimentos...

BOUDET, A. et al. Rapport e contextualisation: France. In: Centres D’Études et de Recherches sur les Qualifications (CÉreQ). Dispositif d'observation des innovations dans le champ de la certification, de la validation et de la reconnaissance des qualifications: rapport intermediaire. Marseille: Ministère de l'Éducation Nationale, de l'Enseignement Supérieur et de la Recherche ; Ministère des Affaires Sociales, 1998. p. 37-49.

BRASIL. Ministerio da Educação. Secretaria de Educação Média e Tecnológica. Proposta de políticas públicas para a educação profissional e tecnológica. Brasília, DF: MEC/SEMTEC, 2003. p. 57.

BRASIL. Ministério de Trabalho e do Emprego. Secretaria de Formação e Desenvolvimento Profissional. Educação profissional: um projeto para o desenvolvimento sustentado. Brasília, DF: MTE/SEFOR, 1995.

BRIGIDO, R.V. Certificação e normalização de competências: origens, conceitos e práticas. Boletim Técnico do SENAC, Rio de Janeiro, v. 27, n. 1, jan./abr. 2001. Disponível em: <http://www.senac.br/informativo/BTS/ 271/boltec271a.htm>

CASTIONI, R. Da qualificação à competência: dos fundamentos aos usos; o PLANFOR como disseminador de novos “conceitos” em Educação. 2002. Tese (Doutorado) - Faculdade de Educação, Universidade Estadual de Campinas, Campinas.

CORDÃO, F. (Rel.). Organização de um Sistema Nacional de Certificação Profissional baseada em Competências: SNCPC. Brasília, DF: CNE/Câmara de Educação Básica, 2003. (Processo n. 23001.000212/02 - 52).

CUNHA, L.A. Ensino médio e ensino técnico na América Latina: Brasil, Argentina e Chile. In: Yannoulas, S. (Org.). Atuais tendências na educação profissional. Brasília, DF: Paralelo, 2001. p. 89-110.

DELUIZ, N. A globalização econômica e os desafios à formação profissional. Boletim Técnico do SENAC, Rio de Janeiro, v. 22, n. 2, maio/ago. 1996.

DELUIZ, N. O modelo das competências profissionais no mundo do trabalho e na educação: implicaçôes para o currículo. Boletim Técnico do SENAC, Rio de Janeiro, v. 27, n. 3, set./dez. 2001. Disponível em: <http:/ /www.senac.br/informativo/BTS/273/boltec273b.htm>

DEPARTAMENTO INTERSINDICAL DE ESTATISTICAS E ESTU- 
DOS SÓCIO-ECONOMICOS. (DIEESE). Anuário dos trabalhadores 2000-2001. 2001. Disponível em: <http://www.dieese.org.br>.

DUBAR, C. La formation professionnelle continue. Paris: La Découverte, 1996.

ENGUITA, M. Educación, formación y empleo. Madri: Eudema, 1992.

FERRETTI, C. Formação profissional e reforma do ensino técnico no Brasil: anos 90. Educação \& Sociedade, Campinas, v. 18, n. 59, p. 225269, ago. 1997.

FIDALGO, F. A formação profissional negociada: França e Brasil, anos 90. São Paulo: Anita Garibaldi, 1999.

FIDALGO, F. Certificação Educacional e Profissional: um campo de disputa. In: SEMINARIO NACIONAL DE EDUCAÇÃO PROFISSIONAL: concepções, experiências, problemas e propostas, 2003, Brasília, DF. Anais... Brasília, DF: MEC/SEMTEC/PROEP, 2003. p. 134-135. Disponível em: <http://www.mec.gov.br/semtec>.

FIDALGO, F.; MACHADO, L. (Ed.). Dicionário da educação profissional. Belo Horizonte: Núcleo de Estudos sobre Trabalho e Educação, 2000.

FRIGOTTO, G. A produtividade da escola improdutiva. São Paulo: Cortez; Campinas: Autores Associados, 1984.

FRIGOTTO, G.; CIAVATTA, M. Educar o trabalhador cidadão produtivo ou o ser humano emancipado. São Paulo: IIEP - Intercâmbio, Informaçóes, Estudos e Pesquisas, 2002a. (mimeo.).

FRIGOTTO, G.; CIAVATTA, M. (Coord.). Caminhos para a redefinição a política pública para a educação tecnológica e o sistema nacional de formação profissional continuada: proposiçóes. Niterói: Projeto integrado UFFCNPq, 2002b (mimeo)

FRIGOTTO, G.; CIAVATTA, M.; RAMOS, M. A gênese do Decreto n. 5.154/2004: um debate no contexto controverso da democracia restrita. Revista Eletrônica do NEDATE, Niteroi, 2005.

GELOT, D. Contre la formation tout au long de la vie, pour l'éducation permanente: d'autres propositions pour la formation professionnelle continue. Paris: Fundation Copernic, 2004. 63p. (mimeo.). 
Educação, formação profissional e certificação de conhecimentos...

GENTILI, P. O conceito de empregabilidade. In: SEMINÁRIO NACIONAL SOBRE AVALIAÇÃO DO PLANFOR: uma política de educação profissional em debate, 1999, São Carlos. Cadernos UNITRABALHO, São Carlos, n. 2, 1999.

HIRATA, H. Reestruturação produtiva, trabalho e relações de gênero. Revista Latinoamericana de Estudios del Trabajo, Buenos Aires, v. 4, n. 7, p. 5-27, 1998.

HIRATA, H. Apresentação. In: Moraes, C.; Ferretti, C. (Coord.). Diagnóstico da formação profissional: ramo metalúrgico. São Paulo: CNM-CUT/ Rede UNITRABALHO, ARTCHIP, 1999.

HOMS, O. Reflexiones entorno al sistema de formación en Espãna. Herramientas: Revista de Formación y Empleo, Barcelona, n. 69, p. 6-9, 2003.

JOBERT, A.; MARRY, C.; TANGUY, L. (Org.). Éducation et travail en Grande-Bretagne, Allemagne et Italie. Paris: A. Colin, 1995.

JOUBIER, J.-M. Mettre la formation professionnelle au service du patronat: a propot du rapport De Virville. Analyses \& Documents Economiques: cahiers du Centre Conféderal d'Études Économiques et Sociales de la CGT), n. 71, p. 4-6, mars 1997a.

JOUBIER, J.-M. Formation professionnelle: ouvrir largement le débat. Analyses \& Documents Economiques: cahiers du Centre Conféderal d'Études Ëconomiques et Sociales de la CGT, n. 71, p. 7-10, mars $1997 \mathrm{~b}$.

LIMA, A. Certificação: a visão do MTE (Ministério do Trabalho e Emprego). Brasília, DF, 2003. (mimeo.). (Texto de apoio à exposição do autor, diretor do departamento de Qualificação Profissional do MTE no Conselho Nacional de Educação. E-mail: almerico.lima@mte.gov.br)

LOPES NETO, S. Certificação Educacional e Profissional: um campo de disputa. In: SEMINÁRIO NACIONAL DE EDUCAÇÃO PROFISSIONAL: concepçóes, experiências, problemas e propostas, 2003, Brasília, DF. Anais... Brasília, DF: MEC/sEMTEC/PROEP, 2003. p. 139-148. Disponível em: <http://www.mec.gov.br/semtec $>$.

LOPES NETO, S.; CODAS, G. Sistema nacional baseado em competências: comentário ao documento do MEC (elaborado para efeitos de apresentação das posições da CUT no seminário realizado pelo MEC, em 
Brasília, 22/2/2000). In: Para discutir certificação: material de apoio. São Paulo: IIPE, 2000. p. 65-68.

MACHADO, L.S. O "modelo de competências" e a regulação da base curricular nacional e de organização do ensino médio. Trabalho \& Educação, Belo Horizonte, n. 4, p. 79-99, ago./dez. 1998

MACHADO, L.S. Implicações da institucionalização da noção e competências. In: Para discutir certificação: material de apoio. São Paulo: IIPE; Belo Horizonte: NETE/UfMG, 2003. p. 88-94.

MACHADO, L.S.; FIDALGO, F. (Org.). Dicionário da educação profissional. Belo Horizonte: NETE/SETASCAD, 2000. 416p.

MERTENS, L. Competência laboral: sistemas, surgimiento, modelos. Montevideo: CINTERFOR, 1996.

MORAES, C.S.V. Política e formação profissional no Brasil e em alguns países europeus. In: ENCONTRO NACIONAL DA ASSOCIAÇÃO BRASILEIRA DE ESTUDOS DO TRABALHO, 4., 1995, São Paulo. Anais... São Paulo: ABET, 1997. v. 1.

MORAES, C.S.V. Notas para a discussão qualificação x competência: apenas uma questão semântica? São Paulo, 1998. (mimeo.). (Parte II-Texto elaborado para a representação da CUT no MerCosul - Comissão Temática "Emprego, Migrações, Qualificação e Formação Profissional”).

MORAES, C.S.V. A relação trabalho-educação e o "novo conceito de produção": algumas considerações iniciais. In: Moraes, C.S.V.; FerretTI, C. (Coord.). Diagnóstico da formação profissional: ramo metalúrgico. São Paulo: CNM-CUT/Rede UnitrabalHO; Artchip., 1999. p. 15-28.

MORAES, C.S.V. Educação, trabalho e formação profissional. In: PrADO, M.L.C.; Vidal, D.G. (Org.). À margem dos 500 anos: reflexões irreverentes. São Paulo: EDUSP, 2002. p. 41-61.

MORAES, C.S.V. O ensino técnico, a formação profissional e o mundo do trabalho: algumas questôes de método. In: Zibas, D.; Aguiar, M.; Bueno, M.S. (Org.). O ensino médio e a reforma da educação básica. Brasília, DF: Plano, 2003. p. 201-224.

MORAES, C.S.V.; FIDALGO, F; DELUIZ, N.; LOPES NETO, S. Considerações sobre a organização de uma política nacional de certificação pro- 
Educação, formação profissional e certificação de conhecimentos...

fissional. In: Para discutir Certificação. São Paulo: IIPE; Belo Horizonte: NETE/ ufmG, 2003. (Texto Subsídio ao Seminário de Educação Profissional mec/ SEMTEC/PROEP, Brasília, DF, 16 a 18 de junho de 2003).

OLIVEIRA, J.B. Novos rumos a formação profissional. In: SEMINÁRIO INTERNACIONAL FIEMG. 1995.

ORGANIZAÇÃO INTERNACIONAL DO TRABALHO (OIT). Projeto: "Avanço Conceitual e Metodológico da Formação Profissional no Campo da Diversidade no Trabalho e da Certificação Profissional", desenvolvido pela Organização Internacional do Trabalho (OIT) e a Secretaria de Políticas Públicas de Emprego do Ministério do Trabalho (MTE). Disponível em: <http://www.ilo.org/public/portugue/region/ampro/ brasilia/info/download/index.htm>.

ORGANIZAÇÃO INTERNACIONAL DO TRABALHO (OIT). Certificação de competências profissionais: discussões. Brasília, DF: OIT; MTE/ FAT, 1999. 144p. Disponível em: <http://www.ilo.org/public/portugue/ region/ampro/brasilia/info/download/index.htm>.

ORGANIZAÇÃO INTERNACIONAL DO TRABALHO (OIT). Certificação de competencias profissionais: análise qualitativa do trabalho, avaliação e certificação de competências; referenciais metodológicos. Brasilia, DF: OIT, 2002. 288p. Disponível em: <http://www.ilo.org/ public/portugue/region/ampro/brasilia/info/download/index.htm>.

ORGANIZAÇÃO INTERNACIONAL DO TRABALHO (OIT). Certificação de competências profissionais: relatos de algumas experiências brasileiras. Brasília, DF: OIT, 2002. 304p. Disponível em: <http:// www.ilo.org/public/portugue/region/ampro/brasilia/info/download/ index.htm>.

RAMOS, M.N. A pedagogia das competências: autonomia ou adaptação? São Paulo: Cortez, 2001.

SALM, C. A adequação dos Planos de Educação Profissional às necessidades Regionais. In: SEMINÁRIO NACIONAL SOBRE AVALIAÇĀO DO PLANFOR: uma política de educação profissional em debate, 1999, São Carlos. São Carlos, 1999. 4p. (mimeo.).

SALM, C.; SABOIA, J.; GONZAGA, P. Política de formação profissional com foco na demanda. 1999. (mimeo.). 
SENAI. Departamento Nacional. Projetos Estratégicos Nacionais "Competências: Formação Profissional" e "Competências: Certificação Profissional”. Brasília, DF, 2002. Disponível em: <http://www.dn.senai.br/ sb63/competencias63.htm> e <http://www.dn.senai.br>.

SINGER, P. Aprender economia. São Paulo: Brasiliense, 1986.

TANGUY, L. La formation, une activité sociale en voie de définition? In: Coster, M.; Pichaut, F. (Org.). Traité de sociologie du travail. Bruxelles: Boeck-Wesmael, 1994. p. 169-196.

TANGUY, L. De la evaluación de los puestos de trabajo a la de las cualidades de los trabajadores: definiciones y usos de la noción de competencias. In: Toledo, E.G.; NefFa, J.C. (Coord.). El futuro del trabajo, el trabajo del futuro. Buenos Aires: CLACSO/ASDI, 2001.

VARGAS ZÚNIIGA, F. Clasificaciones de ocupaciones, competencias y formacion profesional: ¿paralelismo o convergencia? In: SEMINÁRIO INTERNACIONAL "MERCADO DE TRABAJO Y DINÁMICA OCUPACIONAL”, 2002, Belo Horizonte. Belo Horizonte: SENAI-DN, 2002. Disponível em: http://www.cinterfor.org.uy/public/spanish/region/ampro/ cinterfor/publ/sala/vargas/clasific/index.htm 